Sofie Areljung is a doctoral student in educational work at the Department of Science and Mathematics Education, Umeå University. She is also part of the Graduate School for Gender Studies and the Postgraduate School for Educational Sciences, both based in Umeå University. Her background is in science and mathematics teaching in primary and secondary school, and her research involves science, epistemology and physical environment in preschool (school form for children aged 1-5 years).

\title{
Science verbs as a tool for investigating scientific phenomena - a pedagogical idea emerging from practitioner-researcher collaboration
}

\begin{abstract}
This paper communicates the pedagogical idea of approaching scientific phenomena through verbs. The idea has sprung from a collaboration between preschool practitioners and a researcher, addressing science education in preschool (children aged 1-5 years). Drawing on a joint problem inventory, the project group aimed to create a teaching model that supports inquiry-oriented approaches to science, and teachers' ability of distinguishing chemical processes and physics phenomena in everyday practice. The core idea of the teaching model turned out to be a list of everyday verbs, connected to scientific phenomena. Starting from verbs appear to help teachers to recognise the scientific phenomena in everyday practice. Further, the verbs guide the formulating of questions that can be answered by scientific inquiry, such as: "what matters to how something melts/rolls/mixes?".
\end{abstract}

The goal of this article is twofold, one being to present experiences from a design-based practitionerresearcher collaboration, particularly the issues of power and ownership in a process where participants join in at different stages. A second goal is to present the pedagogical idea that has emerged from this collaboration, namely the idea of using science verbs as a tool for investigating chemical processes and physical phenomena in everyday practices.

\section{DEVELOPING A TEACHING MODEL FOR SCIENCE IN PRESCHOOL THROUGH A DESIGN-BASED PROCESS}

The complex problems in education call for innovation with both researchers and practitioners involved, where the context is a core part of the process (Edelson, 2002; Gutiérrez \& Penuel, 2014). One way of conducting such collaboration is to follow a design process, where goals are formulated by practitioners and researchers jointly, and where a model addressing these goals is developed through 
implementation in practice (Reeves, McKenney, \& Herrington, 2011). Accordingly, a starting principle for the project presented here was to involve practitioners already at the initial phases, and that the project should produce meaningful change in practice as well as in research (The Design-Based Research Collective, 2003). The current project follows a design process where the goals are based on needs identified in preschool practice and in research in science education in early years. The aim is to create a teaching model that corresponds to these goals, and to develop it through implementation in preschool practice (Figure 1).

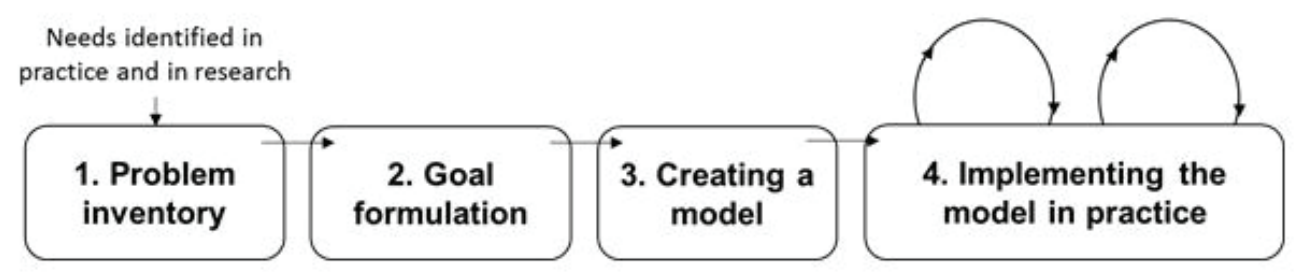

Figure 1. The design process. The phases of the process include (1) a problem inventory and (2) goal formulation, followed by (3) creating a model that corresponds to the goals and (4) developing the model trough implementation in practice.

The pedagogical idea that will be presented in this paper has grown out of a collaboration between myself (the author) and five persons working in a professional development center, funded by a Swedish municipality. These persons, from here on referred to as educators, have long experience from working in preschools, but are currently carrying out in-service training for preschool teachers by supervising work teams and arranging courses and network meetings. Through their work the educators have, in some form, been in contact with most preschool teachers in the region, which was valuable as we started our project with a problem inventory concerning science in preschool. The experiences of the educators, combined with my experience from school science teaching and re-search in early childhood science education, meant that we as a group had a wide-ranging background in relation to preschool science. It also meant that the interface of our different competences was one where new ideas, that none of us could have developed of on our own, could emerge (cf., Engestrom \& Sannino, 2010), as our disciplines adapt to each other (cf., Allen \& Kitch, 1998).

In the initial three phases of the project; problem inventory, goal formulation, and creating a model; the educators and I met three times. The meetings, which were recorded and transcribed, lasted for about two hours and I made reflective notes after each one. We have jointly formed the agendas, and I have continuously shared my summaries from the meetings.

\section{IDENTIFYING NEEDS AND FORMULATING GOALS FOR THE PROJECT}

During the problem inventory, the educators posited that the preschool staff in the region, including themselves, lacked strategies for inquiry-oriented approaches to science and that they needed support in how to interpret the concepts "chemical processes" and "physical phenomena", articulated in the curriculum goals (Swedish National Agency for Education, 2011, p. 11). Further their experience was that science activities in preschool tended to take a form of occasional "happenings", often in the form of spectacular experiments isolated from the daily practices. This was why the educators recognised a need for science teaching to be better intertwined with daily practice. Since preschool practice should take its starting point in children's interests (Swedish National Agency for Education, 2011), the educators saw the necessity of building science education on children's own explorations and questions. 
The educators' call for change of science teaching in preschool coincided with my experiences from research in the field. However, I recognised that it could be challenging to follow children's interest when teaching science. Results from a previous research project implied that, in Swedish preschools, the science learning object became fragmented and elusive due to the teachers' wish to follow children's interests, since these interests could take turns away from a science content (Sundberg et. al, 2015). Based on these findings, I recognised the need of developing models for science teaching that focus children's agentic exploration of scientific phenomena (Siry \& Max, 2013) and support teachers to conduct child-centered, investigative practices (Cremin, Glauert, Craft, Compton, \& Stylianidou, 2015).

Based on the identified needs, we formulated two main goals for what our model-to-be should support: 1) teachers' ability to distinguish chemical processes and physical phenomena in everyday practice, 2) inquiry-oriented approaches to science.

\section{STARTING TO THINK ABOUT SCIENCE IN TERMS OF VERBS}

In the initial meetings, and intertwined with the problem inventory and goal formulation, the collaborating group discussed what science in preschool could be. Drawing on our different experiences, we saw that it is common to talk of science themes in terms of nouns, for example "water", "forest", "trees" and "the body". This sparked us to consider the potential of instead focusing verbs when working with science in preschool. We found that the verbs that came up during our discussion - that was, floating, melting, sticking, and freezing - inspired us to think differently about science. Their "everyday character" was key. For example, we discussed a case of children playing with cloths and water. The children found out that the wet cloths could stick to the wall while dry cloths did not stick. We judged the colloquial concept "stick" to be a fairly accessible concept to address the chemical process involved in the cloth-and-wall situation, compared to the formal concept "adhere". One of the educators, who expressed that she was unsure of how to work with science in preschool, suggested that if teachers would have access to science-related verbs like the ones we were discussing, they would realise that they "know a lot about this already". Further the verbs matched our goal of helping teachers to distinguish physical phenomena and chemical processes. This since processes and phenomena signal that something is "going on", or changing, which better applies to verbs than to nouns.

When considering the possibilities of approaching science through verbs rather than nouns, we discussed the, in preschool and school science, very common theme "water". If one's teaching builds on a water theme it is possible that one will highlight that water can freeze to ice and then melt again, or that water can evaporate. The focus is then on the water and on its different phases solid, liquid, and gas. But, and this is the first twist, if one's eyes are attuned to verbs, like melting or freezing, one may still work with water and ice, though primarily interested in the process of melting, and how different factors - for example shape, temperature, and insulation material - affect melting. And, and this is the other twist, one may wonder what else melts - for example chocolate, ice cream or butter - and what does not melt. By doing that one approaches the process at a more general level, acknowledging that melting and freezing are not specific for water and ice, but that those verbs address the transitions, of any substance, between the different phases solid, liquid, and gas.

\section{Creating a Verb-BASEd MOdel fOR SCIENCE IN PRESCHOOL}

The reason that the educators and I decided to continue working with the verb idea was primarily because it had such an impact on our thinking about science in preschool. The everyday verbs helped us to see scientific phenomena that we had not recognised as easily before, for example the wet cloth sticking to the wall. This connects to what Webster and Mertova (2007) call a "critical event", thus an event that has profound impact on the people experiencing it, in some way changing their views on 
the world. Motivated to discover where the verb idea could lead, we decided that I should form a list of verbs connected to physics and chemistry. In that way we could have a common ground to draw from in our future work. One criterion was that the verbs should be colloquial enough for a teacher, with no specific background in science, to grasp. The list has been revised since then, and below is a current version (see table 1 and 2, a version in Swedish is added as an appendix):

Table 1. Examples of chemistry verbs, seeing chemistry as: studies of how different substances are composed, of their properties, how they change and what happens when different substances mix.

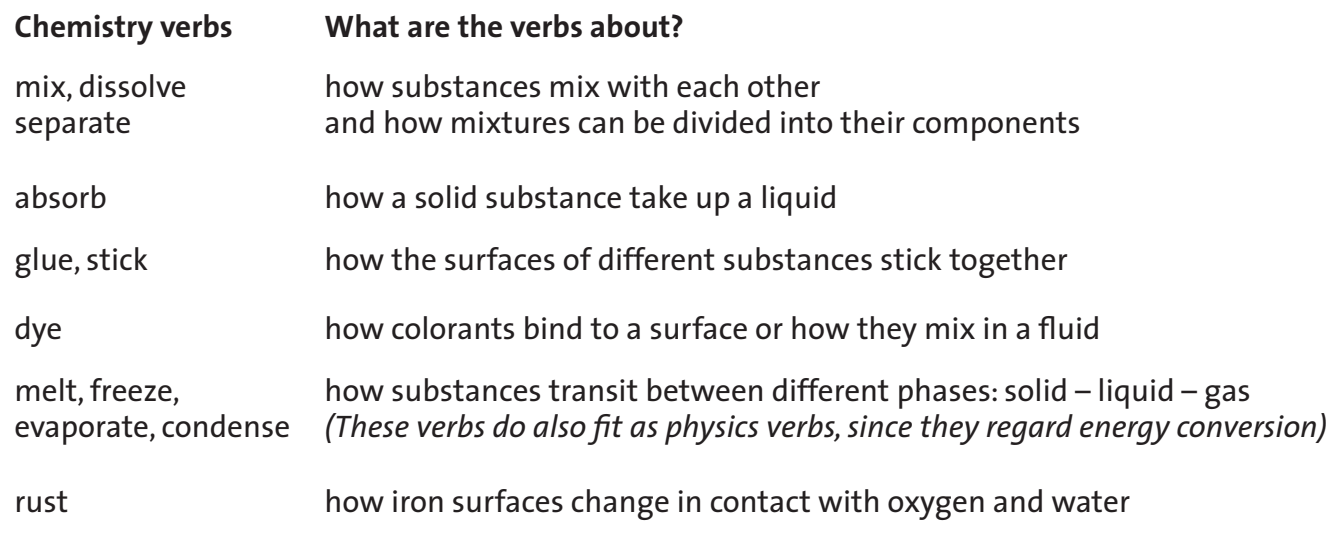

Table 2. Examples of physics verbs, seeing physics as: studies of matter, energy and energy conversion; force and motion.

Physics verbs
spin, rotate, swing
roll
pull, push, lift
fall, flow
topple, balance
bounce
stick
shine, reflect, shade
sound, echo
float, sink

\section{What are the verbs about?}

movements around a central point

movements around a central point, and sideways, towards a surface

exerting a force on something, often with the intent to move objects by overcoming forces like friction (when pulling and pushing) or gravity (when lifting)

movements due to the force of gravity

how objects tip over if their center of mass is outside the surface they are standing on

how objects "return" after hitting a surface

how objects stick to each other due to magnetism or static electricity

light waves and sound waves and how they move in spaces

the buoyancy (lifting force) of liquids and how well objects float 


\section{VERBS AND WORLD VIEWS}

Looking for scholarly work connected to verbs in science, I found that Halliday (1996), in his studies of the development of scientific writing, identified a grammatical turn in the time of modern science, for example in Isaac Newton's writing, from using verbs and adjectives to reshaping them in forms of nouns. Halliday posits that this grammatical turn implies that the "original semantic status (as process or property) is replaced by that of an abstract theoretical entity - thus motion and distance are no longer synonymous with moving and (being) far" (Halliday 1996, p.30). The nounification discussed by Halliday concerns abstract nouns, which can be contrasted to the concrete nouns, such as "water" and "trees", that preschool science themes often revolve around. Yet the discussion is interesting in terms of the shift of valuing nouns over verbs in science. Further it is ties on to Borden's (2011) intriguing example of how the use of nouns and verbs connects to world views. Borden highlights that traditional mathematical language is object-oriented, for example preferring the noun "multiplication" to the verb "multiply". This she contrasts to the indigenous language Mi'kmaw, which is verb- or event-oriented. For example, the Mi'kmaw equivalent to the English word "straight" more literally means "it goes straight", thus embedding a sense of movement in the concept. Another example is that a Mi'kmaw concept for "triangle" was recently developed for school use, but the concept is difficult for many people to visualise since its staticity is not aligned with the grammar. In Mi'kmaw, concepts describing forms are rather expressed as lines or faces moving and meeting. Borden's work thus indicates that the use of verbs in language correlates with world view. A related idea comes out of the work of (Barad, 2007), who proposes a world view where phenomena, and not objects, are seen as the primary ontological entity. Applying Barad's idea to the verb/phenomena "floating", as in a leaf floating on the surface of a water puddle, would mean that "floating" comes first, while the objects the water and the leaf - come second, as their properties emerge in the floating.

Altogether the work of Halliday (1996), Borden (2011) and Barad (2007), suggests a connection between the foregrounding of either objects or processes and one's way of seeing the world, which resonates strongly with the experiences, in the project group, of thinking about science through verbs. As mentioned above, the verbs helped us to see phenomena that we had not recognised before in our everyday life. Could the verbs also help preschool teachers to more easily distinguish scientific phenomena in their everyday practices?

\section{IMPLEMENTING THE VERB IDEA IN PRACTICE - INVOLVING MORE PARTICIPANTS IN THE PROJECT}

Since we were interested in whether the verbs could facilitate preschool teachers' work with science, we engaged preschool teachers to test and develop the idea in practice (Figure 2). The particular preschool was chosen by the educators, based on the fact that the teachers had already demonstrated an interest in cooperating with the center, and since one of the teachers had recently gone through inservice training regarding science and technology in preschool. The staff consists of both preschools and child-minders, which is common in Swedish preschools. For the ease of reading I will refer to all staff as teachers, since this paper does not emphasise the qualifications of the individual staff. The preschool consisted of three units for children aged 1-5 years, with three or four teachers working in each unit. Altogether there were 10 teachers and 54 children in the preschool. 


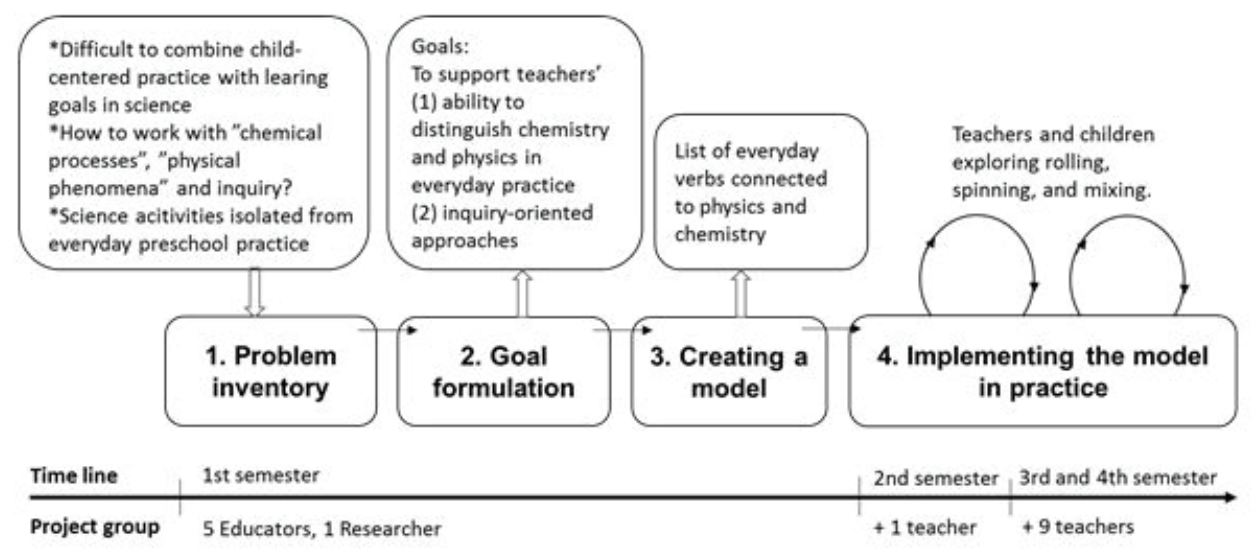

Figure 2. The content and timeline of the design-based process of the project.

The project timeline can be divided in four semesters. In the first semester the project group consisted of the five educators and me. From the second semester and onwards the verb idea was implemented in preschool practice. The teachers received the list of verbs and learnt that the educators and I were, in this first round of testing, particularly interested in the verbs mixing, separating, rolling and spinning. There were no instructions on how to work with the verbs, but the teachers were asked to collect photos and videos from their verb-related activities. During this semester, the teacher who had recently gone through in-service training regarding science took part in the monthly project meetings with the educators and me. During the third and fourth semester the implementation phase continued and all ten teachers, the five educators, and I, met six times. The meetings, which were audio recorded, lasted for around two hours and included discussions about the preschool practices based on photos and videos recorded by the staff.

Over the three semesters of implementation, the preschool teachers have worked with verbs such as rolling, spinning, mixing, separating, dissolving, absorbing, floating, and sinking. Below follow examples of such activities. The accounts are formed based on the project data, that is, the photos and videos collected by the teachers, and the audio recordings from the project meetings. Since one goal of this paper is to present the pedagogical idea of using science verbs, however not to examine its impact on preschool practice, I present two anecdotes in order to exemplify how the teachers and children worked with the verb idea. One anecdote seeks to illustrate how one verb can be explored in many ways, and the other how the teachers' and children' foci move between several verbs in one series of activities. In a forthcoming paper, the empirical data will be systematically analysed in terms of how and why the verb idea developed in practice.

\section{Children exploring "rolling" in different ways}

In one of the preschool units, the teachers and children kept a "rolling" theme evolving for a whole year. Several activities took place in a big field with teachers encouraging children to roll their own bodies. Some children tried to perform a "friend roll", with the goal to roll parallel to each other down a hill, discovering that they were diverging away from each other (Figure 3). In another, recurring, activity the children made different objects roll in paint and on pieces of paper either by pushing the objects or by tilting the paper. The teachers and children suggested to try painting with paper balls (Figure 4), wooden wheels, straws, eggs, apples, and toy cars as well as non-round items. The physical phenomena were focused by teacher questions like: How does it roll? What do the marks from 
the rolling look like? Do things roll differently and why is that, is it because of the shape, weight or surface? Further the children were invited to collect, using a tablet, four items that roll. In order to solve the task, they tried the rolling-capacity of several items, and photographed their favourite four (Figure 5). The task then expanded into documenting four things that do not roll, for example a chair. When asked by teachers why those do not roll, some of the children proposed that the items were too flat or too "squarey".
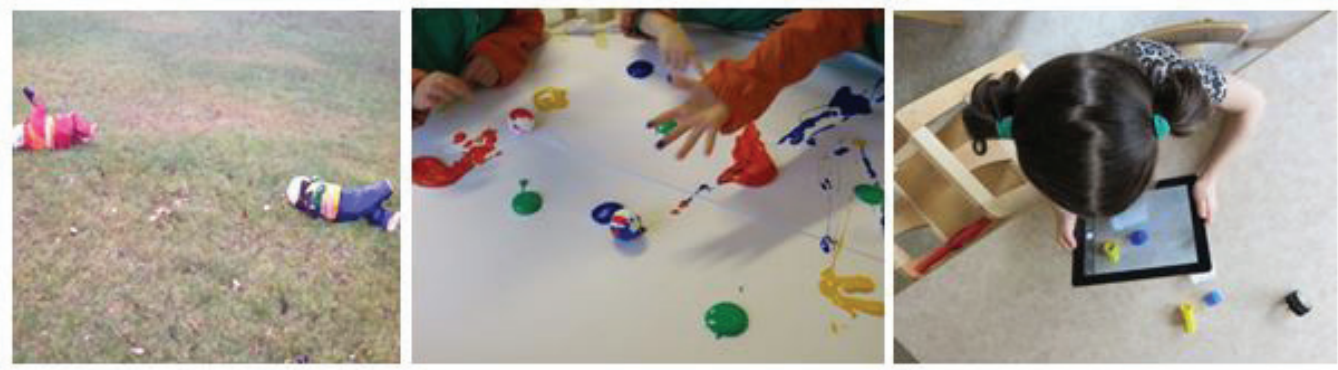

Figure 3. Two children performing a "friend roll", trying to roll in parallel to each other down a slope. Figure 4. Paper balls rolling on paper and through piles of paint. Figure 5. Documenting items that roll and do not roll.

\section{Children investigating the same set of material and several different verbs}

In another preschool unit, one series of activities included big containers of water and paper balls with yellow and red surfaces (Figure 6). When setting up the material, the teachers' idea was that the children would explore how the paper balls float or sink in water. This they did, but soon the balls absorbed water, which made it possible to tear them apart. The balls were only dyed on the surface, and white on the inside, and after a while there was a mix of water and red, yellow, and white paper in the container (Figure 7). The teachers then asked: Could we make this into paper balls again? Despite being skeptical at first, the children grabbed the paper-water-sludge and realised that they could press water out of it, and also form it into balls again. The balls were then left to dry (Figure 8), and compared to what "original" paper balls looked and felt like. The teachers asked the children if they thought that the paper balls could be dissolved in water again, and thus the activities went back-andforth between mixing and separating the paper balls and the water. While the previous example shows several different ways of working with one verb, "rolling", this series of activities involving water and paper balls, shows that several verbs were addressed, such as "floating", "sinking", "dissolving", "mixing" and "separating".
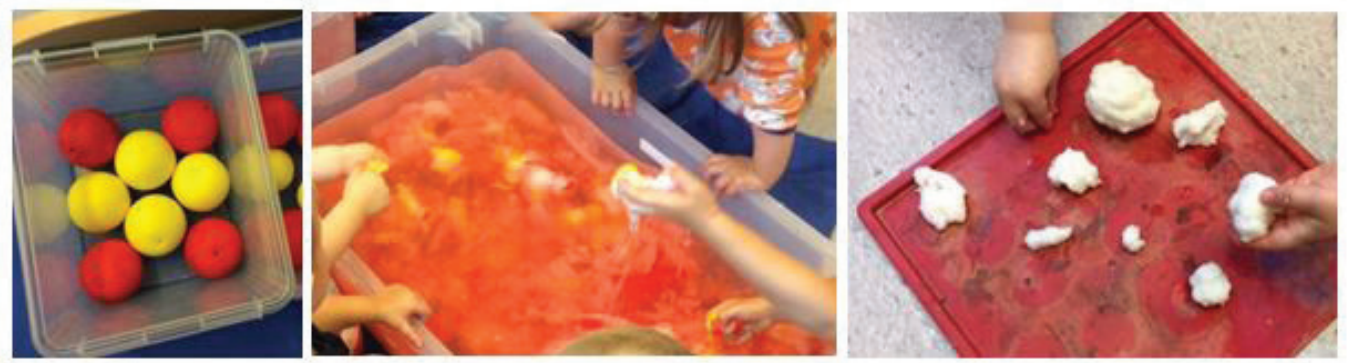

Figure 6. Red and yellow paper balls. Figure 7. A mixture of paper balls and water. Figure 8. A mixture of water and dissolved paper balls has been formed into new balls and left to dry on a tray . 


\section{CONSIDERING THE PEDAGOGICAL POTENTIAL OF THE VERB IDEA}

The idea of shifting from nouns to verbs when framing science activities is, in a sense, a fairly simple one. Nevertheless, it seems to have the potential to drive changes in both practice and research. As a complement to nounificated science (cf., Halliday 1996), the above examples show that the science verbs support teachers' framing of science activities in preschool. In both the examples, children explore scientific phenomena partly guided by teacher questions. The science verbs work to form a template for questions that lead to investigation, such as: "does everything roll/mix etc., everywhere?" and "what affects to how something rolls/mixes etc.?" These questions lead towards varying factors, such as material, shape, size, colour, temperature, and incline. In the example of children explaining why some items do not roll, they used concepts to address the variation, which in this case was that some items were too flat or "squarey". This is an example of how the exploration of science verbs generates a need for additional concepts. While investigating how different objects roll down a slope, a need for scientific concepts emerge, for example the need for a concept such as gravity, to addresses what causes things to roll down. Other necessary concepts concern how the surface of the slope differs, for example friction, incline, or topography, and how the objects differ in terms of shape and inertia. The interplay between colloquial and scientific concepts connects to the concept of "small science", coined by Sikder and Fleer (2015). "Small science" frames the everyday concepts that have to do with science - for example, "push", "pull", and "roll" - and that are interlaced with scientific concepts, like the more abstract "force". Though most of the exemplified "small science" concepts are verbs, Sikder and Fleer do not speak of verbs explicitly. Nevertheless, their study is an interesting input to how everyday-like verbs can contribute to children's learning of scientific concepts. I posit that having a familiar concept, such as the verbs in table 1 and 2, at the center of an investigation supports the child's ownership and control over the investigation. This makes way for science teaching where, as (Siry, 2013, p. 2426) puts it, "[children's] own investigations could position them as the experts on their experiences in the natural world", which in turn suggests that science activities can be framed within child-centered pedagogy. Such child-centered science teaching is a contrast to previous reports on child-centered pedagogy making the science learning object elusive and fragmented (Sundberg et al., 2015).

\section{CONSIDERING POWER RELATIONS IN DESIGN-BASED RESEARCHER-PRACTITIONER COLLA- BORATION}

In retrospect, I think that the project's organisation, with the combination of participants and the "open" start without a predetermined intervention, was advantageous for the development of the verb idea. Yet the project's organisation accentuates how power relations matter in this type of practitioner-researcher collaboration, where participants join at different stages (see Figure 2). Embedded in the idea of practitioner-researcher collaborations is, apart from enhancing the relevance to practice (Gutiérrez \& Penuel, 2014), often that all participants should experience agency and ownership (Akkerman, Bronkhorst, \& Zitter, 2013). Instead of practice serving as a "test bed" for research-initiated interventions, Akkerman et al. (2013) argue, the power should be distributed as both parties contribute in formulating problems and goals, as well as developing the model to be tested in practice. In the reported case, the preschool practice did in one sense serve as a "test bed", since the verb idea did not originate from the preschool teachers who tested and developed the idea in practice. Still the verb idea was not entirely researcher-initiated, but the result of a collaboration with educators in a pedagogical development center. The idea that the teachers were asked to "test" was very rough, basically a set of verbs, and they could use it in the ways they found possible and suitable, with (increasing) possibilities to discuss their experiences with the educators and me. However, at the beginning, the teachers did not experience the agency that we had hoped for. After a few months, we learnt that they initially had been unsure of what was expected from them. Thus an important insight is that there should have been a meeting with all participants before starting the implementation phase. This meeting should have served to outline the verb idea and discuss the expectations that the teachers, the 
educators, and I had on each other. Further at least one representative from each of the three units should have been included in the project group, instead of one representative in total. The sole teacher who was part of the project group during the second semester was put in a difficult position, mediating between the preschool (what had happened with the verb idea in all three preschool units) and the project group (what was our feedback on what had happened). This tension was relieved from the third semester and onwards, when the project meetings included all teachers.

As Gutiérrez and Penuel (2014) emphasise, the complex problems in education require context to be a core part of the research process. In this project, context has been key. In the hands of teachers and children, the verb idea has grown from a list of concepts on a piece of paper to material, bodily activities in the context of preschool practice. Consequently, the meaning of science verbs has diverged from the idea initially formed by the educators and me. Engestrom and Sannino (2010) point out that different stakeholders produce different meanings of the concepts central to their collaborative learning. The concepts change as these meanings are confronted and negotiated. In our case, what is meant by verbs-based science in general, as well as the meaning of the particular verbs, has changed due to the joint discussions on teachers' accounts, pictures, and videos from verb-based activities with preschool children. At first, my mind was set on whether the verbs could support teacher's and children's fair testing of scientific phenomena. My understanding of what the verbs could mean to science education was broadened as I learnt about the many, to me, unforeseen approaches, such as the embodied and aesthetic dimensions of children exploring "rolling" and "mixing".

Though the ownership and agency has shifted with time, as the verb idea has moved from the "sketch table" to taking shape in preschool practice, I have experienced a rather stable position of being in charge of the project. I have also experienced being positioned as a science expert by the teachers and educators, while I in turn positioned them as experts on preschool practice. I have not been fully comfortable with the science expert status, aware that, in society, science and scientists often are positioned as superior in credibility (Harding 1986). The combination of different areas of expertise have been crucial to this project, as the verb idea emerged in the interface (cf., Allen and Kitch, 1998) of the teachers' and educators' knowledge of desirable and possible ways to work in preschool practice, and my knowledge of possible physics and chemistry verbs. Power relations played an important part here. Being positioned in charge of the project and also as a science expert, I needed to work against my and others' perceptions of my perspective being the most credible. This work was crucial to prevent our fruitful interface to collapse into one favored perspective.

As previously mentioned, there is work ahead when it comes to outlining how and why the verb idea evolved in the preschool practices. Still, the aspiration is that this paper has inspired to thinking a bit differently about science education, and that it has contributed insights regarding power relations in practitioner-researcher collaboration.

\section{ACKNOWLEDGMENTS}

My gratitude goes to the educators at the pedagogical development center, and to the teachers and children at the preschool. Thank you for contributing to this joint enterprise of verb-based science, for innovation that none of us could have done on our own. And thank you Anders Hofverberg, for your fruitful feedback and thorough readings of the earlier drafts of this paper. 


\section{REFERENCES}

Akkerman, S., Bronkhorst, L., \& Zitter, I. (2013). The complexity of educational design research. Quality \& Quantity, 47(1), 421-439. doi:10.1007/s11135-011-9527-9

Allen, J. A., \& Kitch, S. L. (1998). Disciplined by Disciplines? The Need for an Interdisciplinary Research Mission in Women's Studies. Feminist Studies, 24(2), 275-299. doi:10.2307/3178698

Barad, K. (2007). Meeting the universe halfway. London : Duke University Press.

Borden, L. L. (2011). The "Verbification" of Mathematics: Using the Grammatical Structures of Mi'kmaq to Support Student Learning. For the Learning of Mathematics, 31(3), 8-13.

Cremin, T., Glauert, E., Craft, A., Compton, A., \& Stylianidou, F. (2015). Creative Little Scientists: exploring pedagogical synergies between inquiry-based and creative approaches in Early Years science. Education 3-13, 43(4), 404-419. doi:10.1080/03004279.2015.1020655

Edelson, D. C. (2002). Design research: What we learn when we engage in design. Journal Of The Learning Sciences, 11(1), 105-121.

Engestrom, Y., \& Sannino, A. (2010). Studies of Expansive Learning: Foundations, Findings and Future Challenges. Educational Research Review, 5(1), 1-24. doi:10.1016/j.edurev.2009.12.002

Gutiérrez, K. D., \& Penuel, W. R. (2014). Relevance to Practice as a Criterion for Rigor. Educational Researcher, 43(1), 19-23. doi:10.3102/0013189X13520289

Halliday, M. A. K. (1996). Writing science: literacy and discursive power. In J. R. Martin (Ed.). London : Falmer Press.

Harding, S. G. (1986). The science question in feminism. Ithaca: Cornell University Press.

Reeves, T. C., McKenney, S., \& Herrington, J. (2011). Publishing and perishing: The critical importance of educational design research. Australasian Journal of Educational Technology, 27(1), $55-65$.

Sikder, S., \& Fleer, M. (2015). "Small Science": Infants and Toddlers Experiencing Science in Everyday Family Life. Research In Science Education, 45(3), 445-464. doi:10.1007/s11165-014-9431-o

Siry, C. (2013). Exploring the Complexities of Children's Inquiries in Science: Knowledge Production Through Participatory Practices. Research In Science Education, 43(6), 2407-2430. doi:10.1007/ s11165-013-9364-z

Siry, C., \& Max, C. (2013). The Collective Construction of a Science Unit: Framing Curricula as Emergent From Kindergarteners' Wonderings. Science Education, 97(6), 878-902. doi:10.1002/ sce. 21076

Sundberg, B., Areljung, S., Due, K., Ekström, K., Ottander, C. \& Tellgren, B. (2015) Understanding preschool emergent science in a cultural historical context through Activity Theory. European Early Childhood Education Research Journal, 24(7), 567-580. doi: 10.1080/1350293X.2016.1189722

Swedish National Agency for Education. (2011). Curriculum for the Preschool Lpfö 98 revised 2010. Stockholm: Fritzes.

The Design-Based Research Collective. (2003). Design-Based Research: An Emerging Paradigm for Educational Inquiry. Educational Researcher, 32(1), 5-8.

Webster, L., \& Mertova, P. (2007). Using narrative inquiry as a research method: an introduction to using critical event narrative analysis in research on learning and teaching. London : Routledge. 


\section{APPENDIX 1: EXAMPLES OF CHEMISTRY AND PHYSICS VERBS (IN SWEDISH)}

Bilaga 1: Exempel på kemiverb, baserat på att kemi är: studier av hur olika ämnen är uppbyggda, vilka egenskaper de har samt hur ämnen förändras och vad som händer när olika ämnen möts.

\begin{tabular}{|l|l|}
\hline $\begin{array}{l}\text { Exempel på kemi- } \\
\text { verb }\end{array}$ & Vad handlar verben om? \\
\hline $\begin{array}{l}\text { lösa, blanda } \\
\text { separera, rena, } \\
\text { sedimentera }\end{array}$ & $\begin{array}{l}\text { Om hur ämnen blandar sig med varandra } \\
\text { och hur blandningar delas upp i sina beståndsdelar }\end{array}$ \\
\hline väta, absorbera & Om hur det ena ämnet sugs upp av/tränger in i det andra. \\
\hline fastna, limma & Om hur ämnens ytor hakar i varandra \\
\hline färga & $\begin{array}{l}\text { Om hur färgämnen binder till ett materials yta, eller blandas med en } \\
\text { vätska }\end{array}$ \\
\hline $\begin{array}{l}\text { smälta, stelna/frysa } \\
\text { förångas/dunsta } \\
\text { kondensera }\end{array}$ & $\begin{array}{l}\text { Om hur ämnen övergår mellan olika faser: fast - flytande - gas } \\
\text { (Passar också bra som fysik-verb, eftersom de rör energiomvandlingar) }\end{array}$ \\
\hline rosta & Om (järn-)ytors förändring i kontakt med fukt och syre \\
\hline
\end{tabular}

Bilaga 2. Exempel på fysikverb. Baserat på att fysik är: studier av energi och energiomvandlingar; kraft och rörelse, ljus och ljud.

\begin{tabular}{|l|l|}
\hline $\begin{array}{l}\text { Exempel på fysik- } \\
\text { verb }\end{array}$ & Vad handlar verben om? \\
\hline $\begin{array}{l}\text { snurra, rotera, } \\
\text { pendla }\end{array}$ & Om rörelser kring en mittpunkt \\
\hline rulla & Om rörelse kring en mittpunkt och i sidled, mot ett underlag \\
\hline dra, knuffa & Om att förflytta föremål (övervinna friktionen) \\
\hline glida, halka & Om rörelser där friktionen är låg \\
\hline bromsa, accelerera & Om att ändra fart... \\
svänga & och riktning \\
\hline falla, rinna & Om att röra sig på grund av jordens dragningskraft. \\
\hline Välta, balansera & $\begin{array}{l}\text { Om att saker välter om deras tyngdpunkt finns utanför ytan som de } \\
\text { stödjer på }\end{array}$ \\
\hline studsa & Om hur ett föremål återvänder efter att ha stött emot något \\
\hline fastna & $\begin{array}{l}\text { Om när magnetiska föremål fastnar i varandra, eller om saker som } \\
\text { fastnar i varandra till följd av statisk elektricitet }\end{array}$ \\
\hline $\begin{array}{l}\text { lysa, spegla, skugga, } \\
\text { låta, eka }\end{array}$ & \begin{tabular}{l} 
Om ljus- och ljudvågor och hur de studsar och bryts \\
\hline flyta, sjunka
\end{tabular} \\
\hline värma, kyla, isolera & Om vätskors lyftkraft och föremåls flytegenskaper \\
\hline
\end{tabular}

